\title{
A Short Analysis of Insertion in Persian
}

\author{
Masoud Dehghan \\ Dept. of Language and Linguistics, University of Tarbiyat Modares, Tehran, Iran \\ Email: masoud.dehghan@modares.ac.ir \\ Aliyeh Kord-e Zafaranlu Kambuziya \\ Depart. of Language and Linguistics, University of Tarbiyat Modares, Tehran, Iran \\ Email: akord@modares.ac.ir
}

\begin{abstract}
This paper investigates epenthesis process in Persian to catch some results in relating to vowel and consonant insertion in Persian lexicon. This survey has a close relationship to the description of epenthetic consonants and the conditions in which these consonants are used. Since no word in Persian may begin with a vowel, so that hiatus can't be considered immensely in Persian. But there are several reasons to reject such a substantial claim; as the best well-known of them is clitics, such as; plural suffix /-an/, nominalizer/adjectivizer suffix /-i/, and also the bound morpheme "to be"/-ast/. Obviously, these morphemes begin with a vowel because of dependency on their before words, thus as a result it occurs hiatus. In order to resolve hiatus, it should be inserted an epenthetic consonant between them. With respect to the features of this epenthetic consonant, it should be said that it doesn't create any distinctive meaning and so it doesn't place in contrast with any phoneme. Since the speaker has no authority in the choice of this epenthetic consonant, thus it isn't distinctive and just has the structural function, as well as it is still inserted for the context recovery and suitable syllable structure in Persian. Furthermore, this process shows that a consonant insertion in different languages is the phonological pattern used for the world constraint recovery in phonotactics, so that it has a close relationship with syllable structure. Also, the presented study evaluates its analysis within the framework of optimality theory (Prince \& Smolensky, 1993). This theory employs a notion of constraint dominance and a mechanism for selecting the optimal output with respect to a set of ranked constraints.
\end{abstract}

Index Terms - insertion, epenthesis, hiatus, epenthetic consonant, optimality theory, Persian

\section{INTRODUCTION}

Epenthesis process (henceforth EP), as a morphophonemic process, often occurs in phonology of different languages and it causes to insert a phonemic element within a word or at the two - morpheme boundary. On the other hands, in EP it is inserted a consonant between two vowels in order to resolve hiatus. And sometimes it is a vowel inserted between two consonant to break consonant cluster because there is no initial consonant cluster in Persian syllabic structure (Kambuzia, 2007, pp. 273-274). EP can be detected in different languages. Some linguists believe that EP is the insertion of a vowel or consonant at the initial of a word or between the sounds. It often occurs in language learning when the language that is learned has different combinations of vowels and consonants in the mother's tongue of learner per se. for example Iranians learning English language often pronounce the English word 'espeak' [espi:k] instead of 'speak' [spi:k]. Therefore, it is a vowel inserted at the initial position of a word in Persian language since no initial consonant cluster exists as the aforementioned. Unlike English language, most of other languages like Persian don't use the combinations such as $/ \mathrm{lm} /$ or $/ \mathrm{lp} /$ as initial consonant cluster, so that the speakers of these languages can epenthesize a vowel between the initial consonant cluster to break it. For instance, Persian speakers pronounce the English word 'Florida' as [felorid $\alpha$.

In general, it must be noted about consonant insertion between two vowels that, should two similar phonological elements situate in contiguity to each other, it produces an ungrammatical structure. In this case, it can refer to a phonological constraint obtained only from a non-linear representation that McCarthy has stated it, the so- called Obligatory Contour Principle (OCP):

"Not two similar elements should be situated in the contiguity to each other."

Since the epenthetic segments do not create meaningful distinction in the language and they aren't in contrast with other phoneme, as if the speaker has no interference in their selection, as well as based on the theory of Prague School Phonologists (PSP), they cannot be called "phoneme", so that it will be argued over the field of phonetics. But in contrast, J.R. Firth, who is the founder of the first linguistics department at the University of London in England and also a person whose name is suffused with the London School, lampoons the theory of PSP. Therefore, he introduces a theory by which language sound elements are divided into two separate parts: one of them is called 'phoneme' and the other is 'prosodies'.

Since the epenthetic consonant situates in the two-morpheme boundary or two-syllable, so that they can belong to the larger units of phoneme which are prosodies or prosodic units. Emerging such consonant to resolve hiatus in Persian is the part of process which phoneticians call it 'epenthesis'. 


\section{Vowels in PeRsian LANGUage}

Persian language, also known as Farsi, is a member of the Iranian branch of the Indo-European languages and a subfamily of the Indo-Iranian languages. It is the national language of Iran, and is spoken in countries like Afghanistan and Tajikistan, too.

In Persian, words consist of one or more syllables. The syllable consists of one obligatory vowel potentially surrounded by consonants. Therefore, a vowel functions as the syllable nucleus and a consonant occurs at the margins of the syllable. Furthermore, Farsi syllables always take one of these patterns (i.e., V, CV, CVC, CVCC, VC, and VCC) presented in Table1 below:

TABLE 1:

PERSIAN SYLLABLE STRUCTURE

\begin{tabular}{|c|c|c|c|}
\hline PHONETIC FORM & PHONOLOGICAL FORM & PERSIAN SYLLABLES & MEANING \\
\hline ?u: & u: & $\mathrm{V}$ & او \\
\hline bu: & bu: & $\mathrm{CV}$ & بو \\
\hline bar & bar & $\mathrm{CVC}$ & بر \\
\hline sard & sard & $\mathrm{CVCC}$ & سرد \\
\hline $\mathrm{Pab}$ & $a b$ & $\mathrm{VC}$ & آب \\
\hline Pabr & abr & VCC & ابر \\
\hline
\end{tabular}

Vowels like Consonants are the basic elements of each language. Persian language has two sets of vowels. On the other hand, it has a six-vowel system, with three long vowels $(/ \mathrm{i} /, / \mathrm{u} /, / \mathrm{a} /)$ and also three short vowels $(/ \mathrm{e} /$, /æ/, /o/). The discrepancy between these two sets of vowels is usually appropriated to be a difference in length, so that lax vowels are short and tense vowels are long (Comrie, p. 526). But the shortening and lengthening of vowels in Persian isn't contrastive since they are in contrast together qualitatively and this factor causes the difference between vowels and the difference in length is a kind of redundancy. (Kambuziya, 2009, p.118)

TABLE 2.

PERSIAN VOWELS IN IPA. (1999, P. 124)

\begin{tabular}{|l|l|l|}
\hline & front & back \\
\hline high & i & u \\
\hline middle & e & o \\
\hline low & $\mathrm{a}$ & $\mathrm{a}$ \\
\hline
\end{tabular}

\section{SIGNIFICANCE OF THE STUDY}

The aim of the presented study is to describe the insertion process (henceforth IP) with the survey of data in Persian language. Based on the Persian Syllabic Structure, the main purposes of this study are several reasons such as resolving hiatus and breaking initial consonant cluster as well as no word may begin with a vowel in surface structure. The presented study tries to illustrate EP in Persian and offers an analysis within the consideration of Optimality Theory (henceforth OT). OT employs a concept of constraint dominance and a mechanism for choosing the optimal output with respect to a set of ranked constraints (for more figuring out of OT, see Prince \& Smolensky, 1993).

\section{THEORETICAL CONSIDERATIONS}

OT is one of the constraint-based approaches emerging at the beginning of 1990's by Prince and Smolensky, and also as the most contemporary linguistic consideration advanced to date, with recent extensions to development. Based on this theory, the candidate, which incurs the least serious violations of a set of violable constraints, is considered as a surface structure (output) and in fact it is 'optimal' output. On the other hand, this theory not only focuses on exploring of allowed surface structure but also denies the non - allowed structures. Like other theories, OT has input-output mechanism.

a. Formal model of OT (adapted from Archangeli, 1997):

(3) GEN given an input representation, GENerator provides a set of potential output forms.

(4) EVAL given the candidate set created by GEN, EVALuator chooses the most optimal or harmonic output for the given input representation.

(5) CON a language-specific ranking of a universal set of CONstraints is used by EVAL in determining the optimal output form.

b. Examples of faithfulness and markedness constraints (McCarthy \& Prince, 1995):

(6) MAX segments in the input must correspond to segments in the output. (No deletion.)

(7) DEP segments in the output must correspond to segments in the input. (No insertion.)

(8) IDENT [FEAT] the place, voice, and manner features of segments of the input must surface in the corresponding segments in the output. 
(9) *COMPLEX avoid consonant clusters.

As shown in the tableau (10) below, once a candidate incurs a crucial violation, there is no way for it to be optimal.

TABLEAU 10

PHONOLOGICAL REPRESENTATION OF CONSTRAINTS (BIJANKHAN, 2006, P. 42)

\begin{tabular}{|l|l|l|l|l|}
\hline Input & $\mathrm{C}_{1}$ & $\mathrm{C}_{2}$ & $\ldots$ & $\mathrm{C}_{\mathrm{n}}$ \\
\hline Cand & $*$ & $* !$ & $\ldots$ & $*$ \\
Cand & $*$ & $* !$ & $\ldots$ & \\
Cand & $* * !$ & & $\ldots$ & \\
$\cdot$ & & & $\cdot$ & \\
$\cdot$ & & & $\cdot$ & \\
. & & &. & \\
Cand & & & $\ldots$ & \\
\hline
\end{tabular}

In general, McCarthy (1988) has illustrated OT like the following box chart:

INPUT

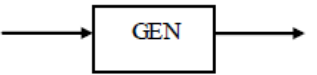

CAN

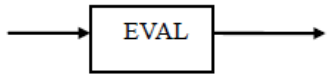

OUTPUT

FIGURE 11. The box chart of optimality phonology model (Bijankhan, 2006, p. 35)

Based on this chart, EVALuator receives the candidate set from GENerator, and evaluates it using some constraint hierarchy, as well as selects its most optimal member as the output of the grammar (McCarthy, 2007, p. 4)

As the aforementioned, in this approach the constraints are two groups which are in complementary distribution together and in fact the optimality is the argument about these distinctions that as a result it selects the optimal output:

a. Faithfulness constraint:

Faithfulness constraints such as the aforementioned are central tenets of OT: They have been shown to have crosslinguistic validity in that they account for a variety of independently motivated patterns (McCarthy \& Prince, 1995).

b. Markedness constraint:

This constraint referred to structural constraints is equally central to OT and have likewise been shown to account for many phenomena cross-linguistically. These constraints require that output forms be unmarked in structure.

\section{INSERTION AND EPENTHESIS}

Before describing and noting some points about these two processes, it is necessary to be noted some points about epenthetic consonant, because they have a close relationship with epenthetic consonant. Epenthetic consonant is that one used over the speech chain to prevent hiatus, usually the first vowel places at the end of previous morpheme and the second one occurs at the beginning of the next morpheme. Generally, Insertion process is a concept that adds a new element to a chain based on which a phonological element is inserted inside a word called EP. In such a process, it inserts a consonant intervocalically to resolve hiatus, or in order to break a consonant cluster, it may insert a vowel between two consonant. According to Firth's point of view, an important figure in the foundation of linguistics as an autonomous discipline in Britain, these elements emerged at the border of between two syllables or two morphemes or even between two words belong to the larger units of phoneme, thus they place in the category of prosodies (FIRTH, 1948, P. 135). This process occurs in different languages that the Persian language is one of them. This paper starts its discussion with the insertion of glottal stop consonant [?].

Based on syllable structure of Persian language and IP, as the aforementioned, the glottal stop insertion at the beginning of the words started with a vowel is necessary.

Based on the definitions coming in English resources such as Kenstowicz (1994) and Crystal (2003), IP is exactly in contrast with ellipsis process in which one vowel or consonant is added to the speech chain to produce a simpler model or syllable structure in phonotactics of that particular language.

Sadeghi (2002) says about consonant insertion between two vowels:

One of the morphophonemic rules in Persian is consonant insertion at the two morphemes boundary, if there is a vowel at the end of the first morpheme and at the initial of the second one in morphology process. He poses it as epenthetic consonant.

Najafi (1999) has noted:

In Persian language, it may be used from some epenthetic consonants such as /-g-/, /-d-/, /-h-/, and sometimes /-v-/, /-j-/ instead of glottal stop consonant [?] ( p. 81). On the other hand, the use of these epenthetic consonants is based on morphological considerations.

According to the common view, there are nine epenthetic consonants in the language; i.e. [?], [h], [j], [g], [c], [t], [d], [w] and [v] (see Majidi,1990, pp. 27-45; Sadeghi, 2002; Bijankhan, 2006, pp. 12-15; Kambuziya, 2007, pp. 277-306.)

\section{A. [?] - insertion}


Generally, word-initial glottal stop insertion is based on the property of Persian Syllable Structure since no word may begin with a vowel in phonetic form. So, if a word begins with a vowel in phonological form, a glottal stop consonant will fill the onset position. Like the examples below:

\begin{tabular}{|c|c|c|}
\hline /abru/ & [?abru] & 'ebrow' \\
\hline /eḑba:r/ & [?edba:r] & 'obligation' \\
\hline /oft $\alpha: \mathrm{d} /$ & [?ofta:d] & 'fell' \\
\hline /a:vard/ & [?a:vard] & 'war' \\
\hline /i:stad/ & [?i:stad] & 'stood' \\
\hline /u:/ & [?u:] & 'he/she' \\
\hline
\end{tabular}

In spite of some linguists who believe that in word-initial position the glottal stop is not epenthetic but phonemic (e.g. Windfuhr, 1979, p. 140), others believe that it is always epenthetic regardless of its position and even in Arabic loanwords (e.g. Lazard, 1957, p.6).

\section{B. Glide Insertion}

However, if one of the prefixes /be-/ or /na-/ places at the initial of the above words, then EP epenthesizes the glide /-j-/ that agrees in features with the contiguous vowel often a 'high vowel' (Lombardi, 2002, p. 9) to resolve hiatus. And based on it, the glide /-j-/ agrees with the high vowel /i/ in Persian. Hence, should the left vowel in hiatus be /i/, the equal glide inserts discussed as a process the so-called 'vowel raising'. See the examples below.

(13)

\begin{tabular}{|c|c|c|}
\hline $\begin{array}{l}/ \text { be-j-oft } \alpha \mathrm{d} / \\
/ \mathrm{be}-\mathrm{j}-\alpha /\end{array}$ & $\begin{array}{l}\longrightarrow \quad[\text { bijoft } \alpha \mathrm{d}] \\
\longrightarrow[\text { bij } \alpha]\end{array}$ & $\begin{array}{l}\text { 'fell' } \\
\text { 'come' }\end{array}$ \\
\hline /be-j-avar/ & [bijavar] & 'bring' \\
\hline /na-j-amad/ & [najamad] & 'didn't come' \\
\hline
\end{tabular}

With respect to these two morphemes be- and $n a-$, Sadeghi (2002) states that they were pronounced be: and $n e$ : in PAHLAVI language. Later, the pronunciation of these two morphemes turned into be- and ne- and then the morpheme $n e$ - changed into $n a$-. But the pronunciation of the morpheme $n e$ - is still current in the most of the areas of Iran like the examples below in LORI dialect in Boirahmad:

$$
\begin{aligned}
& / \text { na-j-amad/ } \rightarrow \text { [nijamad] } \\
& \text { /na-j-avard/ } \rightarrow \text { [nijavard] } \\
& \text { /na-j-andaxt } \rightarrow \longrightarrow \text { [nijandaxt] }
\end{aligned} \quad \begin{aligned}
& \text { 'didn't come' } \\
& \text { 'didn't bring' }
\end{aligned}
$$

(15) *EMPTY assign one violation mark for any consonant without a place specification.

\begin{tabular}{|l|l|l|l|l|}
\hline TABLEAU. 16 & HIATUS & *EMTY & DEP \\
\hline be.jof.tad & & & & $*$ \\
\hline be.1of.tad & & & $* ! \mathrm{W}$ & $*$ \\
\hline be.of.tad & $* ! \mathrm{W}$ & $*$ & & \\
\hline
\end{tabular}

Glides, on the other hand, are typical hiatus breakers, occurring intervocalically in a large number of languages (e.g. Dutch, Booij, 1995; Korean, Kang, 1999; Czech, Rubach,2000 ; Sinhala, Smith, 2001; Japanese, Kawahara, 2002). Conversely, they seem to be rare as default epenthetic segments in word-initial position. Keep in mind, their usage is discrepancy together. [j] is commonly inserted in the context of a front vowel; $[\mathrm{w}]$ is inserted in the context of a back/round vowel. We will exemplify these epenthetic consonants later in this paper.

Generally, The IP of epenthetic consonants can occur in the following ways:

1. The epenthetic consonant/-g-/ only resolve hiatus in the following morphophonologic contexts (Sadeghi, 2002, pp. 34-35; Kambuziya, 2007, pp. 298-300):

a. after the vowel /e/ and before the noun-making suffix $-\mathrm{i}$,

b. after the vowel /e/ and before the plural suffix -an,

c. after the vowel /e/ and before the adverb-making suffix -ane,

d. sometimes after the vowel /a/.

The use of epenthetic consonant $[\mathrm{g}]$ is shown by the examples below.

(17)

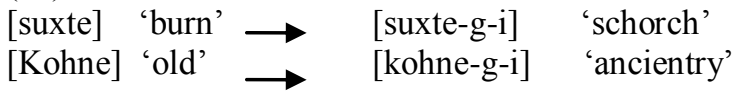




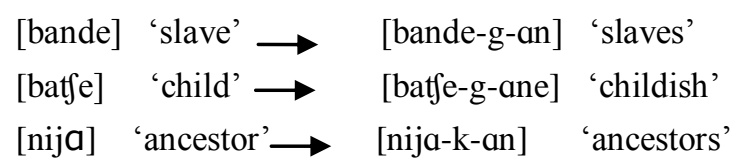

With respect to the example [nijakan] that Najafi (1999) has used it as [nijagan], it can state in which the phoneme $/ \mathrm{k} /$ has already been existed as a floating consonant in underlying representation and it refers to its historical considerations. So the historical considerations can be influenced on selecting of epenthetic segment in some cases. Also, it can refer to the following example in which the epenthetic consonant $/ \mathrm{k} /$ has been inserted:

[pelle] 'stair' $\rightarrow$ [pelle-k-an] 'stairs'

Furthermore, the historical considerations manifests that some words in Middle Persian have had the consonant $[\mathrm{g}] \mathrm{as}$ the final segment historically, but later [g] has been omitted and they end in /e/ in Persian language nowadays. For example, [zende] as [zendag]. But, as the aforementioned, by adding plural suffix /-an/, nominalizer/adjectivizer suffix /-i/ and also the adverbializer /-ane/ to them, it inserts the so-called epenthetic [g] to resolve hiatus. As a result, it may be concluded that the so-called epenthetic [g] just emerges before three suffixes mentioned above.

2. Also, in Persian language the so called epenthetic [h] occurs only in the fixed forms below, i.e. when pronominal enclitics attach to the propositions $b e$ 'to' and $b a$ 'with', as exemplified below.

(19)

\begin{tabular}{|c|c|c|}
\hline $\begin{array}{l}\text { /be-em/ } \\
\text { /be-et/ }\end{array}$ & $\begin{array}{l}\longrightarrow[\text { be-h-em }] \\
\longrightarrow[\text { be-h-et }]\end{array}$ & $\begin{array}{l}\text { 'to me } \\
\text { 'to you (Sing.) }\end{array}$ \\
\hline /be-eš/ & $\rightarrow$ [be-h-ef] & 'to him/her \\
\hline /be-eman/ & $/ \longrightarrow$ [be-h-eman] & 'to us' \\
\hline /be-etan/ & $\rightarrow$ [be-h-etan] & 'to you' (Pl.) \\
\hline $\begin{array}{l}\text { /be-ešan/ } \\
\text { (20) }\end{array}$ & 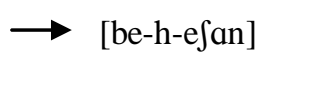 & 'to them' \\
\hline /ba-am/ & $\rightarrow$ [ba-h-am] & 'with me' \\
\hline /ba-at/ & $\rightarrow \quad[$ ba-h-at $]$ & 'with you' (Sing.) \\
\hline /ba-aš/ & $\rightarrow \quad[b a-h-a f]$ & 'with her/him' \\
\hline /ba-aman/ & $/ \rightarrow \quad[$ ba-h-aman $]$ & 'with us' \\
\hline /ba-atan/ & $\rightarrow \quad$ [ba-h-atan $]$ & 'with you' (Pl.) \\
\hline /ba-ašan/ & [ba-h-afan] & 'with them' \\
\hline
\end{tabular}

3. Based on morphological considerations, the epenthetic consonant /d/ is attached only in the forms below which just can occur in literary Persian (see Anvari, 2002, pp. 846-875). On the other hands, this epenthetic consonant occurs in the following contexts:

a. after the preposition /be-/ 'to' and before the demonstrative pronouns / Rin/ 'this', /Ran/ 'that'.

b. after the preposition /be-/ 'to' and before the personal pronouns /iu: / 'he/she', /Ri:šan/ 'they'.

(21)

/be-in/ $\longrightarrow[$ [be-d-in] 'with this'
/be-an/ $\longrightarrow[$ be-d-an] 'with that'
/be-u: $/ \longrightarrow[$ be-d-u] 'to him/her'
/be-i:šan/ $\rightarrow[$ [be-d-i:San] 'to them'

4. Sometimes the epenthetic consonant $/ \mathrm{v} /$ is used before the conjunction word /-o/ as exemplified below.

\begin{tabular}{|c|c|c|c|}
\hline /ale-o-zanbaG/ & $\rightarrow$ & [lale-v (w)-o-zanbaG] & 'tulip and lily' \\
\hline /sara-o-susan/ & & [sara-v (w)-o-susan] & 'Sara and Susan' (Proper names) \\
\hline /kahu-o- kalam/ & - & [kahu-v (w)-o- kalam] & 'salad and cabbage' \\
\hline /Rajne-o-ša:mdan/ & & 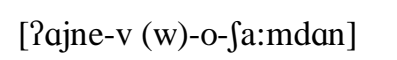 & 'mirror and candlestick' \\
\hline na-o-šoma/ & & [ma-v (w)-o-Soma] & 'we and you' (PL.) \\
\hline nardane-o-zan & & [mardane-v (w)-o- & 'male and female' \\
\hline
\end{tabular}

Eventually $[\mathrm{v}]$ - epenthesis is also attached in a few fossilized forms before the attributive suffix / $-\mathrm{i} /$ as exemplified below: 
/kora-i/ $\rightarrow$ [kora-v-i] 'spherical'

/sari-i/ $\rightarrow$ [sara-v-i] 'from Sari' (a city in the north of Iran)

5. Should two consonants situate in the two-morpheme boundary sequentially and the vowel coming before them be long, the epenthetic vowel /e/ epenthesizs between them as exemplified below.

(24)

\begin{tabular}{|c|c|c|c|}
\hline $\begin{array}{l}\text { /jad-gar/ } \\
\text { /šad-man/ }\end{array}$ & $\rightarrow$ & $\begin{array}{l}\text { [jad-e-gar] } \\
{[\text { Jad-e-man] }}\end{array}$ & $\begin{array}{l}\text { 'memorial' } \\
\text { 'happy' }\end{array}$ \\
\hline /šad-man/ & & [ $\left.\int a d-e-m a n\right]$ & 'happy' \\
\hline $\mathrm{an} /$ & & [saz-e-man] & 'organization' \\
\hline d-gan/ & & [pad-e-gan] & 'soldiers home' \\
\hline az-gar & & [saz-e-gar] & 'compatible' \\
\hline and-gar/ & & [mand-e-gar] & 'persistent' \\
\hline axt-man/ & & [saxt-e-man] & 'building' \\
\hline arvard-gar/ & & [parvard-e-gar] & 'God' \\
\hline ban/ & & [pas-e-ban] & 'policeman \\
\hline $\mathrm{ad}-\mathrm{šah} /$ & & [pad-e-Sah] & 'kinG \\
\hline Jahr-man/ & $\rightarrow$ & [Gahr-e-man] & 'knight' \\
\hline
\end{tabular}

But the so-called epenthetic /e/ is optional at the two-morpheme boundary, so that some of the above words can be produced with no epenthetic/e/.

Moreover keep in mind, /e/- epenthesis doesn't apply in the following compound words at all, as exemplified below.

(25)

$\begin{array}{ll}\text { [gerdbad] } & \text { 'tornado' } \\ \text { [mehrdad] } & \text { 'Mehrdad' (proper name) } \\ \text { [mahrox] } & \text { 'Mahrokh' (proper name) } \\ \text { [Gandar] } & \text { 'creature' } \\ \text { [falguš] } & \text { 'a person who eavesdrop' } \\ \text { [rastgu] } & \text { 'truthful' } \\ \text { [karsaz] } & \text { 'knifesmith' } \\ \text { [zargar] } & \text { 'jeweller' }\end{array}$

Obviously, the above words make up of two bases or stems. So, in this case it can be said that the rule of /e/epenthesis only apply to those words made up of one base and suffix. Thus, it can conclude that the rule of /e/epenthesis apply with respect to morphological considerations. In general, the rule of /e/-epenthesis will be explained in $\S 6$ below.

6. Sometimes /j/-epenthesis inserts after a vowel and before the morpheme /- e/ which is the sign of the so-called Ezafe - construction (genitive form) at the two morphemes boundary. On the other hand, if preceding morpheme ends in a vowel, then in this way [j]-epenthesis will be epenthesized and it will resolve the hiatus regardless of the quality of the preceding vowel, and there is no exception to this rule as exemplified below.

\begin{tabular}{|c|c|c|c|}
\hline $\begin{array}{l}\text { /na-amad/ } \\
\text { /xane-e-man/ }\end{array}$ & $\rightarrow$ & $\begin{array}{l}\text { [na-j-amad] } \\
{[\text { xane-j-e-man }]}\end{array}$ & $\begin{array}{l}\text { 'didn't come' } \\
\text { 'my home' }\end{array}$ \\
\hline /hardo-e-šoma/ & & [hardo-j-e-foma] & 'both of you' \\
\hline /Razema-eš/ & & [?azema-j-ef] & 'expriment' \\
\hline /patu-e-maxmal/ & & [patu-j-e-maxmal] & 'velvet blanket' \\
\hline
\end{tabular}

But unlike the above examples, if the preceding morpheme ends in a consonant, then $/ \mathrm{j} /$ won't be epenthesized as exemplified below.

(27)

$\begin{array}{ll}\text { [pesar-e-zerang] } & \text { 'a clever boy' } \\ \text { [ketab-e-man] } & \text { 'my book' } \\ {[\text { [e? }]} & \text { 'he/she' } \\ \text { [r-e-nima }] & \text { 'Nima's poetry' } \\ \text { [fandak-e-sigar }] & \text { 'cigarette light' }\end{array}$

Najafi (1999) refers to the palatal glide [j] - epenthesis in the word [gu-j-ande] and believes that it inserts to resolve hiatus. But this paper rejects NAJAFI's claim and believes that, in such cases, [j] isn't an epenthetic consonant since /j/ 
exists in the underlying representation as a floating consonant. Furthermore, [j] or [\$] - epenthesis inserts before the plural suffixes [-an,-at] in Persian to resolve hiatus as exemplified below.

a. Plural morpheme [-an].

$\mathrm{i}: \rightarrow \mathrm{ij} /+[-\mathrm{an}]$

(28)

\begin{tabular}{|c|c|c|}
\hline tan/ & & \\
\hline$+a n /$ & [banij-an] & 'spc \\
\hline an / & [?ira & as' \\
\hline$+a n /$ & [ [ji?ij-an] & 'shi \\
\hline ašena: an/ & [?aSenaj-an] & ' $\mathrm{fa}$ \\
\hline šenava: $+a_{r}$ & [naSenavaj-an] & 'deafs' \\
\hline $\begin{array}{l}\mathrm{a}:+\mathrm{an} / \\
\mathrm{l}+\mathrm{an} /\end{array}$ & $\begin{array}{l}\text { [danaj-an] } \\
\text { [binaj-an] }\end{array}$ & $\begin{array}{l}\text { 'wises' } \\
\text { 'sights' }\end{array}$ \\
\hline & & 'studen \\
\hline gक & & \\
\hline
\end{tabular}

b. Plural morpheme [-at].

i: $\rightarrow \mathrm{ij} /+[-\mathrm{at}]$

(29)

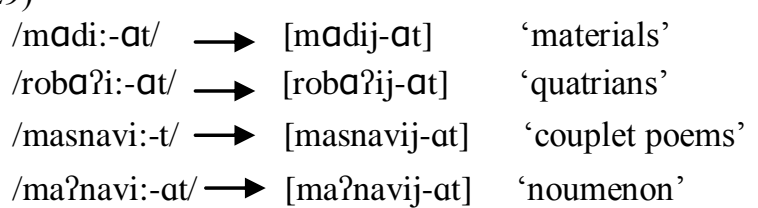

With respect to some examples above, also there is an epenthetic consonant in the phonological literature of Persian that is the voiced affricate [\$] taking place only before the plural morpheme [-at]. This Arabic plural morpheme is synonymous to the plural suffix [-ha] in Persian. See the following examples in this case.

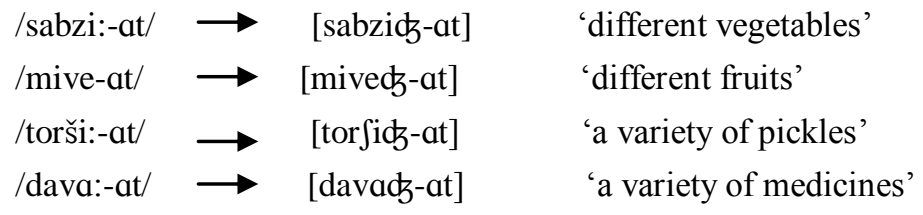

But Kambuziya (2006) states that since the high vowels [i:, u:] are long in Persian, so if they situate at the end of a word and simultaneously we add them the plural morpheme [-an], in this case one part of the high vowel turns into its equal glide [j] or [w], the so-called 'devocalization'(p. 254). Thus the high vowels become short. However, should the left vowel in hiatus be /i/ or / $\mathrm{u} /$, the equal glide $/ \mathrm{j} /$ or $/ \mathrm{w} /$ inserts respectively. See the example below.

(30)

[j]-epenthesis after a front vowel. $\quad\{\mathrm{i}: \rightarrow \mathrm{ij} /-+$ an $\}$

The following examples have been adapted from Sadeghi, 1986:

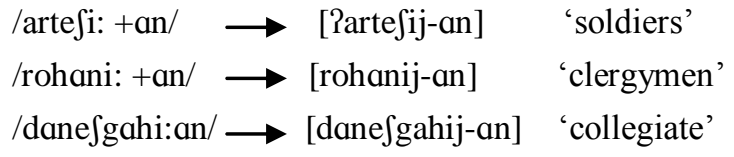

[w]-epenthesis after a back vowel: $\{\mathrm{u}: \longrightarrow \mathrm{uw} / \longrightarrow+\mathrm{an}\}$

/bazu: $+\mathrm{an} / \rightarrow$ [bazuw-an] 'arms'

/ahu: $+\mathrm{an} / \longrightarrow$ [?ahuw-an] 'deers'

/banu: + an $] \rightarrow$ [banuw-an] 'women'

\section{DATA ANALYSIS}

In OT there is a principle the so-called input - output contiguity (IO-CONTIGUITY) based on which segments that are contiguous in the input must be contiguous in the output. Furthermore, in this theory, based on the faithfulness constraint, there should be some resemblance between the input and output to prevent from the creation of a structural gap between input and output. In other words, each phoneme at the left edge of the input must be corresponded with the 
phoneme at the left edge of the output. So based on this constraint, consonant or vowel insertion intervocalically (like the examples in part B below), or between two consonants (like the examples in part $\mathrm{C}$ below) within the words is considered as a violation of this constraint in OT. In the examples below, the vowels located in the contiguity of a consonant $\left(\mathrm{C}_{1}\right)$ in the output are still contiguous with the same consonant but the segment at the left edge of the input is not correspondent with the segment at the left edge of the output and so in this case, it has been violated faithfulness constraint. In other words, the contiguity of the segment in the input and the output has not been violated but the correspondence between them has been violated.

a. Glottal stop insertion:

Since no word in Persian language should begin with a vowel, Based on Persian Syllable Structure, it should be inserted a glottal stop consonant / / at the initial of words started with a vowel. In other words, so if a word begins with a vowel in Persian language, then the empty onset position should be filled with a glottal stop consonant. For example, an input form /edbar/ 'obligation' will surface as [?ecboar] in Persian. Generally, Glottal stops are frequently found in the world's languages (for an overview, see Lombardi, 1997) to satisfy an onset requirement. Like the following examples shown in tableau (33):

(32)

\begin{tabular}{|c|c|c|}
\hline /anva?/ & [?anva?] & 'types' \\
\hline /ecbar/ & [?eळbar ] & 'obligation' \\
\hline /oftad/ & [?oftad] & 'fall' \\
\hline /avard/ & [Ravard] & 'bring' \\
\hline stad/ & [?istad ] & 'stand' \\
\hline u:/ & {$[\mathrm{Pu}]$} & 'he/she' \\
\hline
\end{tabular}

TABLEAU. 33

\begin{tabular}{|l|l|l|l|l|}
\hline /edbar/ & ONS & DEP & IO - CONTIGUITY - VC & IO - CONTIGUITY \\
\hline edbar & $* !$ & & & \\
\hline Pecbbar & & $*$ & & $* !$ \\
\hline
\end{tabular}

Glottal stops are inserted in otherwise onset less initial or stressed syllables; an input / edbar / 'obligation' will be realized as [?eלbar]. EP can be modeled as a case of constraint interaction, more precisely, as interaction of two basic constraints, one markedness constraints which demands that first syllables have an onset, and a faithfulness constraint which bans epenthesis. These constraints are ONSET and DEP-IO, formalized below:

(34) ONSET syllables have onsets (Prince and Smolensky, 1993)

(35) DEP-IO output segments have a correspondent in the input (no epenthesis; McCarthy \& Prince, 1995)

b. In the two-morpheme boundary, after the vowel / e / and sometimes after the vowel / a /, usually it is used from the so-called epenthetic [g]. Like following examples in tableau (37) in which one of the constraints has been violated:

(36)

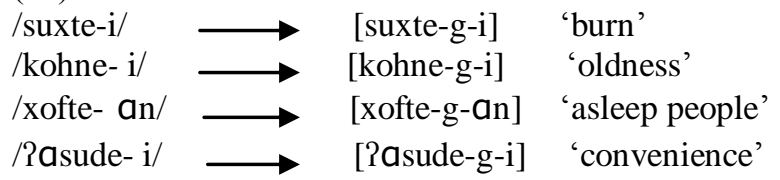

\begin{tabular}{|l|l|l|l|l|}
\hline$/$ Tsuxte+i/ & ONS & hiatus & IO - CONTIGUITY - VC & IO - CONTIGUITY \\
\hline suxte-i & $*$ & $*$ & & \\
\hline suxte-1-i & & & & \\
\hline suxte-g-i & & & & $*$ \\
\hline
\end{tabular}

As shown in the tableau (37), a constraint*[?] will prohibit a glottal stop from appearing in the output intervocalically within the word /suxte+i/; the second-least marked segment, dorsal [g], will then come to the rescue.

c. If two consonant locates at the border of two morphemes sequentially, and the vowel coming before those consonant to be long, then it should be inserted the vowel /e/ between those two consonant. As the following examples seen in tableau 4 below in which has been violated from the second constraint from OT's point of view, because under this approach, all elements of the input chain should be existed in the output while it can be seen in the following examples in which there is no correspondence between the chain elements of input and output:

(38)

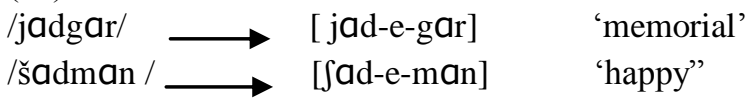




\begin{tabular}{|c|c|c|}
\hline /sazman/ & [saz-e-man] & 'organization' \\
\hline /Gahrman / & [Ghahr-e-man] & 'knight' \\
\hline / ruzgar/ & [ruz-e-gar] & 'period' \\
\hline b/ & 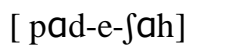 & 'king' \\
\hline
\end{tabular}

The above examples follow the rule below:

(39)

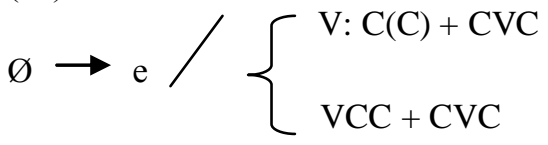

TABLEAU. 40

\begin{tabular}{|l|l|l|l|}
\hline /jad+gar/ & IO - CONTIGUITY - VC & V:C(C) + CVC & IO - CONTIGUITY \\
\hline jad-e-gar & & & $*$ \\
\hline jad+gar & & $* !$ & \\
\hline
\end{tabular}

As shown in tableau (33) above, the candidate [?egbar] has violated the faithfulness constraint because the candidate /egbar/ has been turned into the candidate [?edbar] and it has been inserted the glottal stop consonant at the initial of it. Furthermore, both candidates [suxte-g-i] and [jad-e-gar] respectively shown in the tableau (37) and (40) have violated the faithfulness constraint, too.

\section{CONCLUSION}

Based on Persian Syllabic Structure, there are nine epenthetic consonants in this language. On the basis of an Optimality-Theoretical analysis, in this paper we argued that since no word in Persian may begin with a vowel so that it must insert a glottal stop [?] initially. Also, if an open syllable (i.e. the syllable ending with a vowel) places before a syllable starting with a front vowel, it creates a process which is related to hiatus. In Persian in order to resolve hiatus, an epenthetic consonant inserts between those two vowels. The property of this epenthetic consonant is this that it doesn't place in contrast with any other phoneme. Therefore, the presented study states that there are about nine epenthetic consonant, along with [?]- insertion like; [h], [j], [g], [b], [t], [d], [w] and [v] resolving hiatus.

\section{REFERENCES}

[1] Anvari, H. (2002). Farhange Sokhan [Sokhan Dictionary. Tehran: Sokhan.

[2] Bijankhan, M. (2006.). Avashenasi: nazariyeye behinegi [Phonology: Optimality Theory].Tehran, Samt.

[3] Catford, J.C.(2004). A practical Introduction to phonetics. Oxford University Press.

[4] Catford, J.C. (1992). An Encyclopedic Dictionary of Language \& Languages, Blackwell Publishers.

[5] Comrie, B. (1987). The world's Major Languages. Kent: Croom Helm.

[6] Crystal, D. (2003). A dictionary of Linguistics and Phonetics. Fifth edition. Oxford: Blackwell.

[7] Dehkhoda, A. A. Loghatname [ Dictionary]. Tehran. Dehkhoda Publication Institute. 15 Volumes.

[8] Firth, J. R. (1948). Sounds and prosodies. Transactions of the Philological Society. 127-152.

[9] Haghshenas, A.M. (2001). Avashenasiye zaban-e farsi [Persian phonetics].Tehran: University Publication Center.

[10] INTERNATIONAL PHONETIC ALPHABET. (1999). Handbook of the International Phonetic Association: A guide to the use of the International Phonetic Alphabet. Cambridge, U.K. \& New York, NY: Cambridge University Press.

[11] JABBARI, A.A. \& Arghavan, L. (2010). Optimality Theoretic Account of Acquisition of Consonant Clusters of English Syllables by Persian EFL Learners. Journal of English Language Teaching and Learning, No. 217

[12] Kambuziya, A. K. Z. (2007). Vajshenasi: Ruykardhaye Gha'edebonyad [Phonology: Rule-Based Approaches]. Tehran: Samt.

[13] Kambuziya, A. K. Z. (2009). Hadiyan, B. Tabaghat-e tabiee dar vakehaye zaban-e farsi [Natural classes in Persian vowels]. Scientific-Research Journal. Persian Literature Research. No. 15. 117-144.

[14] Kenstowicz, M. (1979). Chukchee vowel harmony and epenthesis. Chicago Linguistics Society. 402 - 412.

[15] Kitto, C. and DeLacy, P. (1999). Correspondence and epenthetic quality. In Proceedings of AFLA VI, Eds. Catherine Kitto and C. Smallwood, Academic Graphics, Holland.

[16] McCarthy, J. (1988). Feature Geometry and Dependency: A Review, Phonetica. 43:84-108.

[17] McCarthy, J. \& Alan P. (1995) Faithfulness and Reduplicative Identity. University of Massachusetts, Amherst, Rutgers University.

[18] McCarthy, J. (2007). What is Optimality Theory? University of Massachusetts. Amherest. 4

[19] Najafi, A. (1999). Mabani zabanshenasi va karbord-e ?an dar zaban farsi [Principles of linguistics and its application in Farsi]. Tehran. Niloofar Publication.

[20] Smolensky, P. (1997). Constraint Interaction in Generative Grammar II: Local Conjunction. Handout of talk presented at the Optimality Theory Workshop. John Hopkins University.

[21] Smolensky, P. \& Prince, A. (1993). Optimality Theory: Constraint Interaction in Generative Grammar. MIT Press. 
[22] Sadeghi, A. A. (1986). Elteghaye mosavvetha va mas'aleye samete miyanji [Hiatus and the problem of epenthetic consonants]. Tehran: Linguistics magazine. Third year. No. 6.

[23] Sadeghi, A. A. (2002). Masa'el-e tarikhiye zaban-e farsi [The historical problems of Persian language]. Tehran. Sokhan. 25-50.

[24] Samare, J. (2002). Avashenasiye zaban-e farsi, avaha va sakhte avaiye heja [Persian phonetics, sounds and syllable phonetic structure]. Tehran. University Publication Center. Sixth print. Second edition.

Masoud Dehghan is from Iran and he was born there in 1978 August 11. He is Ph.D. Candidate in Linguistics at the department of language and linguistics at university of Tarbiyat Modares in Tehran, Iran. Email: masoud.dehghan@modares.ac.ir

He has a permanent exempt in military service. He's teaching English Pre-University book in Kermanshah, Iran from 2001 to 2004. He's teaching English Language at the department of English language and literature at Razi University in Kermanshah, Iran. Also, he's teaching English Language at university of Applied, Science and Technology in Kermanshah, Iran. He's an ENGLISH TEACHER at the department of language and linguistics at Razi University in Kermanshah, Iran. His previous researches are:

1- "Discourse and Otherness: A critical Study of the other in the Recent Discourse on Democracy". Int. Conference on CDA. University of Tasmania.February in 2005.

2- "Stylistics and linguistic variations in Forough Farokhzad's Poems". JLTR academy publisher. volume3, Issue 5. September. 2012

Aliyeh Kord-e Zafaranlu Kambuziya is from Iran and she was born there. She has Ph.D. degree in Linguistics from the department of language and linguistics at university of Tehran's in Tehran, Iran. Email: akord@ modares.ac.ir

She's taught linguistics to students at university of Tarbiat Modares in Tehran, Iran since 1979. Her previous researches are:

1-"Lenition in phonological patterns of Persian". Journal of Humanities, Iran 2003/1.

2-“sonority hierarchy principle in cvec syllable of Persian". Journal of Humanities , Iran 17/10/2006

3-"Arabic Definite Prefix: An Autosegmental Analysis". SALR: South Asian Language Review. 2007

4- "Knowing is Seeing metaphor in Qur'an: A Cognitive Approach to Study of Religious Texts". South Asian Language Review SALR. 2008

5- "An Optimality- Theoretic Account of Dissimilation in Persian”. Journal of Humanities. 2009 